\title{
Income and Wealth Inequality in Malta
}

\author{
Ilias Georgakopoulos ${ }^{1}$ \\ ${ }^{1}$ Economic Analysis Department, Central Bank of Malta, Castille Place, Valletta, Malta \\ Correspondence: Ilias Georgakopoulos, Economic Analysis Department, Central Bank of Malta, Castille Place, Valletta \\ Malta.
}

Received: July 25, 2019

Accepted: August 12, $2019 \quad$ Available online: August 15, 2019

doi:10.11114/ijsss.v7i5.4455

URL: https://doi.org/10.11114/ijsss.v7i5.4455

\begin{abstract}
This paper studies for the first time the distribution of income and wealth in Malta based on three waves of micro-level data from the Household Finance and Consumption Survey (HFCS). The focus of the analysis is to examine various socioeconomic aspects of income and wealth inequality and contributing factors, as well as determinants of the joint distribution of income and wealth. Results suggest that household main residence (HMR) is the most equalising factor of wealth inequality, while self-employment wealth is the most disequalising factor. The financing structure of HMR is particularly important to explain the position of a household in the wealth distribution. Furthermore, the age and education level of the reference person of a household, increases in household income and inheritance or gifts affect positively the probability of a household to be in a higher net wealth quintile.
\end{abstract}

Keywords: wealth and income distributions, inequality, generalised ordered logit model, household, Malta

\section{Introduction}

Since the onset of the recent financial crisis many euro area countries experienced sizeable adverse shocks. At the macro level, gross domestic product (GDP) and employment rates decreased in many euro area counties. At the micro level, households' losses on their incomes and assets were considerable. However, such losses have not been uniformly distributed across different socioeconomic groups. In addition to the above, the crisis of 2008/9 highlighted the importance of credit constraints and marginal propensity of households to consume out of different sources in explaining aggregate consumption dynamics. These developments, have led to a renewed interest in income and wealth inequality, in both academia and policy-making, especially after the publication of "The Capital in the Twenty-First Century" by Piketty (2014) and the results by Stiglitz, Sen and Fitoussi (2009).

Contrary to economic developments in many euro area countries, Malta's performance remained favourable since the start of the crisis. Real GDP growth rate averaged 5.3\% from 2010 to 2017, while the unemployment rate decreased from $7.3 \%$ to $4.0 \%$ in 2017 , despite an increasing labour participation rate. Home-ownership remained elevated at around 82\% in 2017 according to the European Union Survey of Income and Living Conditions (SILC) (Note 1). At the same time, rental costs increased rapidly, potentially amplifying inequality. Thus, developments in Malta's booming housing market are crucial due to the widespread implications they have on wealth, private consumption and on the respective ability of banks and borrowers to lend and borrow.

The data used in this paper are from the Maltese Household Finance and Consumption Survey, first held in 2010 and subsequently in 2014 and 2017. The HFCS collects detailed micro-data on household assets and liabilities, wealth, income, consumption and savings. Most of these questions are answered by the most financially knowledgeable household member, that is, the reference person. There are few papers studying aspects of inequality (see e.g. Darmanin, Georgakopoulos \& Knoppe, 2018) and, more specifically, how it has evolved over time. Furthermore, studies on the wealth distribution are largely lacking in Malta. This paper attempts to fill this gap by examining how income and wealth inequality evolved in a period during which the Maltese economy experienced strong macroeconomic growth.

The first part of the analysis relates to distributional statistics and findings across a variety of dimensions, namely age, employment status and education. In addition, equalising and disequalising factors of the overall income and net wealth inequality are reported by applying Lerman and Yitzhaki's (1985) decomposition method. The second part analyses the joint distribution of income and net wealth by estimating a generalised ordered logit model.

Results indicate that wealth inequality increased moderately but at a quicker pace than that of income inequality 
between 2010 and 2016. Households whose reference person has tertiary education saw sizable increases in their median incomes and net wealth. The Gini coefficient decomposition analysis reveals that labour income drives income inequality, whereas income from pensions decreases it. As regards real assets, household main residence is the most equalising factor for net wealth inequality, while self-employment wealth is the most disequalising one. In contrast, the role of financial assets is rather limited. Analysis of the joint distribution of income and wealth suggests that age, high levels of education and income increase the probability of a household to be in a higher net wealth quintile. Furthermore, the financing structure of the main residence is important in determining the position of a household in the net wealth distribution. Lastly, inheritance or gifts affect positively and significantly the probability of a household to move to a higher quintile of net wealth.

The rest of the paper is organised as follows: section 2 provides a brief overview of the literature. Section 3 describes the data. Section 4 and 5 present the results of the descriptive analysis and socioeconomic dimensions of inequality, respectively. The decomposition of income and wealth by component is presented in Section 6. Section 7 examines the joint distribution of income and wealth. Section 8 concludes.

\section{Literature Review}

Research on inequality has historically used information from various data sources to study the distribution of income and wealth. For example, Bricker et al. (2016) measure income and wealth inequality at the top quintiles in the United States (US) based on administrative data and the Survey of Consumer Finances (SCF). Without accounting for the conceptual differences between the two sources, the estimates of inequality at the top quintiles, based on administrative tax data, are substantially higher than those based on the SCF. On the methodological side of things, the literature has employed different methods, but decomposition techniques have been the most widely used. Shorrocks $(1982,1983)$ and Lerman and Yitzhaki (1985) provide decomposition methods based on the Gini coefficient. Counterfactual analysis is another and more recent technique to study inequality (see e.g. Chernozhukov et al., 2009 and Fortin et al., 2011). Both papers provide an analytical toolkit for applying counterfactual analysis with reference to inequality metrics, broadly defined as the result of either a change in the distribution of a set of covariates that determine the outcome variable, or as a change in the relationship of the covariates with the outcome.

The literature on income inequality and its decomposition is extensive. On the one hand, papers by Machado and Mata (2005) and Bourguignon et al. (2008) examine differences in income and income distribution with respect to differences in socioeconomic and labour market characteristics. On the other hand, Rani and Furrer (2016) apply Lerman and Yitzhaki's (1985) method to decompose the Gini coefficient, based on micro-level data from household surveys in 13 G20 countries. The authors report that labour income is the most significant contributing factor to inequality in all countries, whereas transfers and benefits are the most important factors that reduce inequality.

With respect to wealth inequality, empirical research is more limited due to the availability of good quality data. Existing studies focus predominately on the US. For example, Wolff $(1994,2004)$ track the evolution of US household wealth since the 1960 using the Survey of Consumer Finances. Bilias et al. (2005) use information from the same data source to show that an increased participation rate in risky financial assets does not entail a reduction in the overall inequality of wealth. The literature on European countries was limited until recently, but expanded significantly since the first wave of the HFCS became available to researchers. Early studies include Brandolini et al. (2004) and Azpitarte (2010) who explore the composition and distribution of household wealth in Italy and in Spain, respectively. Both papers show that wealth inequality is mainly driven by inequality in real assets rather than by financial assets. At a broader level, Lindner (2015) examines the distribution of wealth in 15 HFCS participating countries. The author finds that households' main residence contributes a much higher proportion to inequality in comparison to other assets. Similar methodological approaches and findings are documented by Bezrukovs (2013) and Grejcz and Żółkiewski (2017), for the euro area and Poland, respectively.

In recent years, there have been more papers on the determinants of wealth accumulation and the role of intergenerational transfers in wealth inequality. For example, Fessler and Schürz (2015) examine the role of inheritance, income and welfare state policies in explaining differences in household wealth within and between Eurozone countries. The main conclusion of this paper is that social services provided by the state are substitutes for private wealth accumulation and only partly explain observed discrepancies in the levels of households' net wealth across European countries. Leitner (2016), using data from the first wave of HFCS, tries to identify the sources of inequality in household gross, net wealth across eight euro area countries. Dispersion in bequests and inter vivos transfers affects wealth inequality more strongly than the one caused by income differences. Life-cycle considerations in relation to pension wealth and total wealth accumulation are examined by Cowell et al. (2016).

The increasing availability of wealth data has also led to research on the joint distribution of income and wealth. For example, Jäntti et al. (2008) study the joint distribution of income and wealth in Canada, Germany, Italy, Sweden and 
the United States and observe that net wealth and disposable income are highly, but not perfectly correlated between individuals within each country. A paper by Arrondel et al. (2014) explore the distributions of household wealth and income for 15 European countries to provide evidence of heterogeneity in wealth accumulation behaviours. The authors also find that the effect of income or inheritance on wealth accumulation varies, depending on the rank of the households in the wealth distribution.

For the case of Malta, research on inequality from a micro perspective is limited. Betti et al. (2015) use SILC and Census data to assess economic poverty and inequality by district and locality for households with children. Their findings indicate a considerable degree of heterogeneity across localities. More recently, Knoppe (2018) studies the distribution of wage and wage mobility between 2000 and 2015, using administrative data. The main conclusion of the study is that the increased dispersion in the wage distribution reflects structural changes in the Maltese economy, and the sluggish response of the labour supply to the evolving demand. Wealth inequality in Malta has to date been analysed in the context of countries participating in the HFCS without however examining its dynamics and trends over time. This paper attempts to fill this gap.

\section{Data}

This paper is based on data from the Household Finance and Consumption Survey. The survey was conducted for the first time in 2010 and repeated in 2014 and 2017 (Note 2). It includes detailed questions about households' balance sheet, income and consumption patterns, and on specific forms of credit constraints. Most of these questions are answered by the most financially knowledgeable household member, that is, the reference person. The probabilistic design of the survey entails that each household in the target population has an ex ante non-zero probability of being part of the sample, contributing to the representativeness of the survey, while survey weights are adjusted for the non-response items and coverage issues. To address the issue of missing values the dataset is multiply imputed using multivariate imputation by chained equations following the methodology presented in Rubin (1987). In particular, five imputations were made for every missing value.

The unit of analysis is the household. No equivalisation is made in order to take into account differences in household size or composition. The aim of this paper is to investigate wealth and income inequality across households rather than individuals. Moreover, there is no consensus on whether household wealth should be equivalised and common approach to account for household composition effects (Note 3).

Net wealth is defined as the sum of real and financial assets, less liabilities. Real assets consist of the household's main residence, other real estate property, investments in self-employed businesses, vehicles, and other valuables. Financial assets are deposits, securities (bonds), listed shares, voluntary pension scheme investments in mutual funds, and life insurance and other financial assets (e.g. amount owned to household). Housing debt is the outstanding amount of mortgage on the main residence and other property. Liabilities are defined as the outstanding amount of mortgages, loans financing other real estate property, outstanding debt on credit cards and credit lines/bank overdrafts as well as outstanding amounts of other, non-collateralised, loans (including loans from commercial providers and private loans).

Gross household income is a measure of all before-tax income and includes employee income, self-employment income, income from pensions, regular social transfers, regular private transfers, income from real estate property, income from financial investments, income from private business and partnerships and other non-specified sources of income (e.g. income from regular private transfers).

\section{Descriptive Analysis}

\subsection{The Distribution of Income and Net Wealth}

Figure 1 displays the distribution of gross household income and net wealth by percentiles. As can be seen, the distribution of gross household income moved upwards in the period under review, mainly for households between the 60th and 80th percentiles. Income for households in the lowest $30 \%$ of the distribution remained relatively flat. However, the distribution of net wealth did not change as much as the income distribution as accumulation of wealth over the lifetime is a lengthy process and cannot be easily reversed. The most significant changes are noted in the upper parts of the net wealth distribution (80th percentile and upwards), with small changes in the rest of net wealth distribution. 


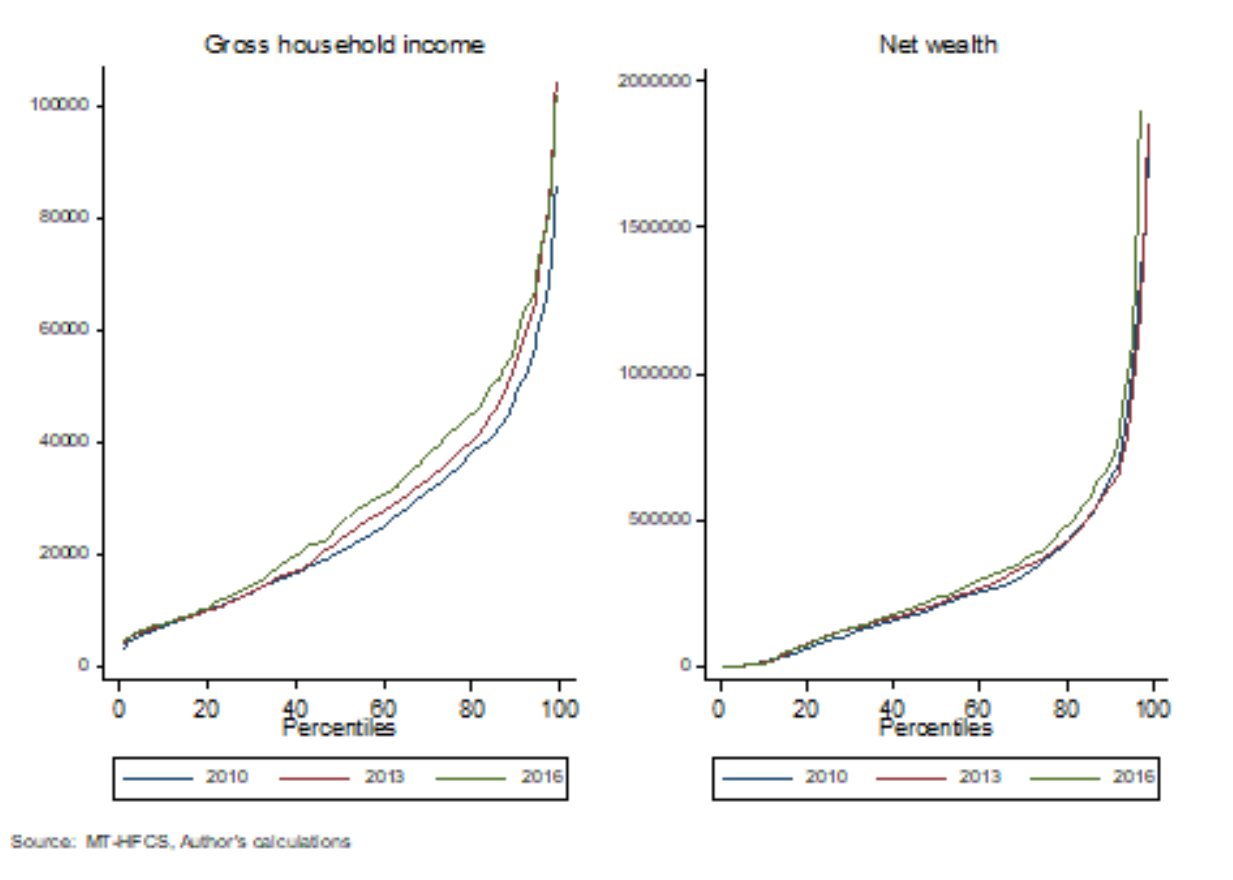

Figure 1. Percentile distribution of gross household income and net wealth

Qualitatively, the percentile plots of real income and real net wealth are very similar and are omitted.

\subsection{Distributional Statistics}

Table 1 reports some widely used measures of inequality for gross household income, net wealth, real assets, financial assets and liabilities. A first observation relates to financial assets, which are the most unequally distributed variable among the ones chosen. This statement is supported by the Gini coefficient and by two of the three relative measures of inequality considered here. For example, the 90-50 ratio, which captures differences in the top half of the distribution, increased at a faster rate than the 50-10 ratio across the three waves, which concerns the bottom half of the distribution. A second observation is that generally inequality increased moderately since 2010 and may even have decreased according to some relative measures. However, this is not the case for financial assets. The Gini coefficient for gross household income, net wealth and real assets increased in the period 2010-16. At a more granular level, the 90-50 ratio decreased in all the variables above, whilst a decrease in the 75-25 ratio is also noted, except for household income. A final observation is the sizeable decrease in the Gini coefficient for household liabilities.

With regards to net wealth, the 90-50 ratio indicates that the gap in the top half of the distribution became less pronounced over time, suggesting that the net wealth of the middle $50 \%$ exerts more weight on the net wealth distribution. This is also supported by the decline in the 75-25 ratio. In contrast, inequality in the bottom half increased as indicated by the rise in the $50-10$ ratio. 
Table 1. Summary of distributional statistics for the sample households

\begin{tabular}{|c|c|c|c|c|c|c|c|c|c|c|}
\hline Variable & Mean & Median & $\mathrm{P} 10$ & $\mathrm{P} 25$ & $\mathrm{P} 50$ & $\mathrm{P} 90$ & $\mathrm{P} 90 / \mathrm{P} 50$ & $\mathrm{P} 50 / \mathrm{P} 10$ & $\mathrm{P} 75 / \mathrm{P} 25$ & Gini \\
\hline \multicolumn{11}{|c|}{ Gross household income } \\
\hline 2010 & 25,299 & 20,562 & 7,292 & 11,657 & 20,562 & 49,022 & 2.38 & 2.82 & 2.97 & 0.378 \\
\hline 2013 & 27,682 & 22,718 & 7,597 & 11,566 & 22,718 & 54,997 & 2.42 & 2.99 & 3.17 & 0.396 \\
\hline 2016 & 31,203 & 25,417 & 7,668 & 12,655 & 25,417 & 58,639 & 2.31 & 3.31 & 3.32 & 0.409 \\
\hline \multicolumn{11}{|l|}{ Net wealth } \\
\hline 2010 & 324,576 & 204,908 & 15,937 & 88,319 & 204,908 & 639,102 & 3.12 & 12.86 & 4.15 & 0.566 \\
\hline 2013 & 340,652 & 212,067 & 14,298 & 107,857 & 212,067 & 612,576 & 2.89 & 14.83 & 3.45 & 0.562 \\
\hline 2016 & 402,611 & 236,529 & 12,612 & 105,600 & 236,529 & 692,368 & 2.93 & 18.75 & 3.87 & 0.598 \\
\hline \multicolumn{11}{|l|}{ Real assets } \\
\hline 2010 & 306,689 & 193,511 & 5,300 & 91,187 & 193,511 & 583,564 & 3.02 & 36.51 & 3.76 & 0.573 \\
\hline 2013 & 327,313 & 209,840 & 19,361 & 129,684 & 209,840 & 574,893 & 2.74 & 10.84 & 2.65 & 0.538 \\
\hline 2016 & 382,895 & 225,752 & 9,387 & 127,302 & 225,752 & 643,001 & 2.85 & 24.05 & 2.98 & 0.584 \\
\hline \multicolumn{11}{|l|}{ Financia l assets } \\
\hline 2010 & 46,860 & 23,454 & 1,876 & 7,562 & 23,454 & 104,856 & 4.47 & 12.50 & 7.73 & 0.622 \\
\hline 2013 & 53,140 & 22,150 & 2,722 & 8,184 & 22,150 & 140,101 & 6.33 & 8.14 & 6.81 & 0.653 \\
\hline 2016 & 57,498 & 22,512 & 1,751 & 7,000 & 22,512 & 130,166 & 5.78 & 12.86 & 8.36 & 0.679 \\
\hline \multicolumn{11}{|l|}{ Liabilities } \\
\hline 2010 & 39,868 & 17,122 & 496 & 3,057 & 17,122 & 105,201 & 6.14 & 34.52 & 14.67 & 0.682 \\
\hline 2013 & 46,676 & 19,273 & 401 & 2,134 & 19,273 & 131,949 & 6.85 & 48.09 & 36.09 & 0.643 \\
\hline 2016 & 63,937 & 40,000 & 1,000 & 6,500 & 40,000 & 162,751 & 4.07 & 40.00 & 15.91 & 0.559 \\
\hline
\end{tabular}

The distribution of gross household income is less concentrated than that of net wealth as indicated by lower Gini values. In 2016, households at the top of the income distribution earned 2.31 times more than those at the median of the distribution, down from 2.38 in 2010. Concurrently, households in the middle-to-upper parts of the distributions saw higher increases in income, which resulted in small increases in the Gini values over the period under review.

Overall inequality in liabilities, measured by the Gini index, dropped to 0.55 in 2016 , from 0.68 in 2010 . The main driver of the reduction in the Gini coefficient is the increasing availability of housing loans to households in the bottom half of the distribution since 2010. By the end of 2016, the 90-50 ratio dwindled from 6.14 to 4.07 as liabilities held by households at the median of the distribution grew by $134 \%$. Strong increases in household debt are also noted in the lower parts of the debt distribution (i.e. P10 and P25).

\subsection{Distributional Statistics Decomposition}

To further investigate what drives inequality, the same analysis as in the previous subsection is repeated. However, the sample size is restricted to households whose reference person is between 20 and 60 years old, which broadly corresponds to the working-age category in Malta (see Table 2).

Inspection of Table 2 indicates that the picture of inequality changes somewhat for gross household income and financial assets. For gross income, the Gini index is lower by some 0.04-0.05, while all of the displayed percentiles ratios are lower. This suggests that the group of pensioners pushes up overall measures of inequality since their incomes are considerably lower compared to those of other low income households. Inequality in financial assets also decreases.

It therefore appears that life-cycle features play an important role in determining the level of gross household income and financial asset holdings. However, their impact on real assets and net wealth is rather limited as inequality indicators for the working-age households are close to those for the whole population. This is because most pensioners are asset rich at the household level, but income poor. It should be mentioned that the 50-10 ratio drops significantly for working-age households, indicating that there is higher inequality among retired households in the bottom of the net wealth and real assets distribution. 
Table 2. Summary of distributional statistics for working-age households

\begin{tabular}{|c|c|c|c|c|c|c|c|c|c|c|}
\hline Variable & Mean & Median & P10 & P25 & P50 & $\mathrm{P} 90$ & $\mathrm{P} 90 / \mathrm{P} 50$ & P50/P10 & $\mathrm{P} 75 / \mathrm{P} 25$ & Gini \\
\hline \multicolumn{11}{|c|}{ Gros s household income } \\
\hline 2010 & 29,209 & 25,872 & 10,088 & 15,668 & 25,872 & 51,398 & 1.99 & 2.56 & 2.48 & 0.334 \\
\hline 2013 & 32,651 & 28,685 & 10,211 & 17,080 & 28,665 & 59,578 & 2.08 & 2.81 & 2.40 & 0.342 \\
\hline 2016 & 38,976 & 33,301 & 12,630 & 21,027 & 33,301 & 65,281 & 1.96 & 2.64 & 2.25 & 0.357 \\
\hline \multicolumn{11}{|l|}{ Net we alth } \\
\hline 2010 & 346,872 & 218,672 & 24,107 & 107,819 & 218,672 & 642,187 & 2.94 & 9.07 & 3.40 & 0.565 \\
\hline 2013 & 360,607 & 214,859 & 36,494 & 117,060 & 214,859 & 569,684 & 2.65 & 5.89 & 3.08 & 0.567 \\
\hline 2016 & 418,487 & 237,690 & 30,802 & 118,452 & 237,690 & 681,328 & 2.87 & 7.72 & 3.49 & 0.601 \\
\hline \multicolumn{11}{|l|}{ Reala ssets } \\
\hline 2010 & 333,278 & 204,709 & 7,154 & 108,085 & 204,709 & 598,118 & 2.92 & 28.62 & 3.20 & 0.576 \\
\hline 2013 & 353,780 & 215,448 & 40,247 & 134,807 & 215,448 & 559,190 & 2.60 & 5.35 & 2.54 & 0.552 \\
\hline 2016 & 409,102 & 228,752 & 17,501 & 135,302 & 228,752 & 640,001 & 2.80 & 13.07 & 2.84 & 0.581 \\
\hline \multicolumn{11}{|l|}{ Fina ncia l as sets } \\
\hline 2010 & 41,918 & 22,937 & 1,339 & 7,938 & 22,937 & 103,018 & 4.49 & 17.13 & 7.32 & 0.586 \\
\hline 2013 & 45,319 & 22,067 & 2,930 & 8,673 & 22,067 & 110,181 & 4.99 & 7.53 & 6.10 & 0.614 \\
\hline 2016 & 49,696 & 21,520 & 1,590 & 6,667 & 21,520 & 100,000 & 4.65 & 13.54 & 8.33 & 0.654 \\
\hline \multicolumn{11}{|l|}{ Liabilities } \\
\hline 2010 & 42,017 & 18,701 & 500 & 4,174 & 18,701 & 113,000 & 6.04 & 37.40 & 11.35 & 0.667 \\
\hline 2013 & 51,549 & 24,900 & 467 & 3,826 & 24,900 & 138,000 & 5.54 & 53.27 & 21.28 & 0.619 \\
\hline 2016 & 68,941 & 45,946 & 1,200 & 10,000 & 45,946 & 175,001 & 3.81 & 38.29 & 10.95 & 0.531 \\
\hline
\end{tabular}

\section{Socioeconomic Dimensions of Inequality}

Some household characteristics such as age, education and employment status are related to income and wealth. For example, wealth could influence one's decision on whether to invest in further education, which could have an impact on employment outcomes or on decisions to purchase assets that generate future income stream. Figure 2 examines how median income and net wealth are distributed across different age cohorts, by level of education and employment status of the reference person.

\subsection{Inequality by Age}

The top panel of Figure 2 shows median income and net wealth by age. As can be seen, income and net wealth display the typical hump shape that is found in the literature and usually attributed to the life-cycle profile. Median income tends to monotonically increase until the age of the household's reference person reaches 45-54, where it peaks. It declines thereafter because of retirement.

\subsection{Inequality by Employment Status}

The middle panel of Figure 2 depicts the distribution of income and net wealth according to the employment status of the reference person (Note 4). Employee income has been on the rise since 2010, which contrasts with a relatively flat profile for self-employed income. In fact, while median self-employed income initially was broadly equal to median employee income, by 2016 it stood lower. However, differences in employee and self-employed income remain relatively small. Regarding net wealth, the self-employed, which account for less than $8 \%$ of the sample in each of the three waves, on average, had 2.4 times the net wealth of employees in 2010, who are the majority of households (around $40 \%$ of respondents). In 2016, this ratio stood lower, at 2.1, reflecting a decrease in the median net wealth of self-employed persons. 

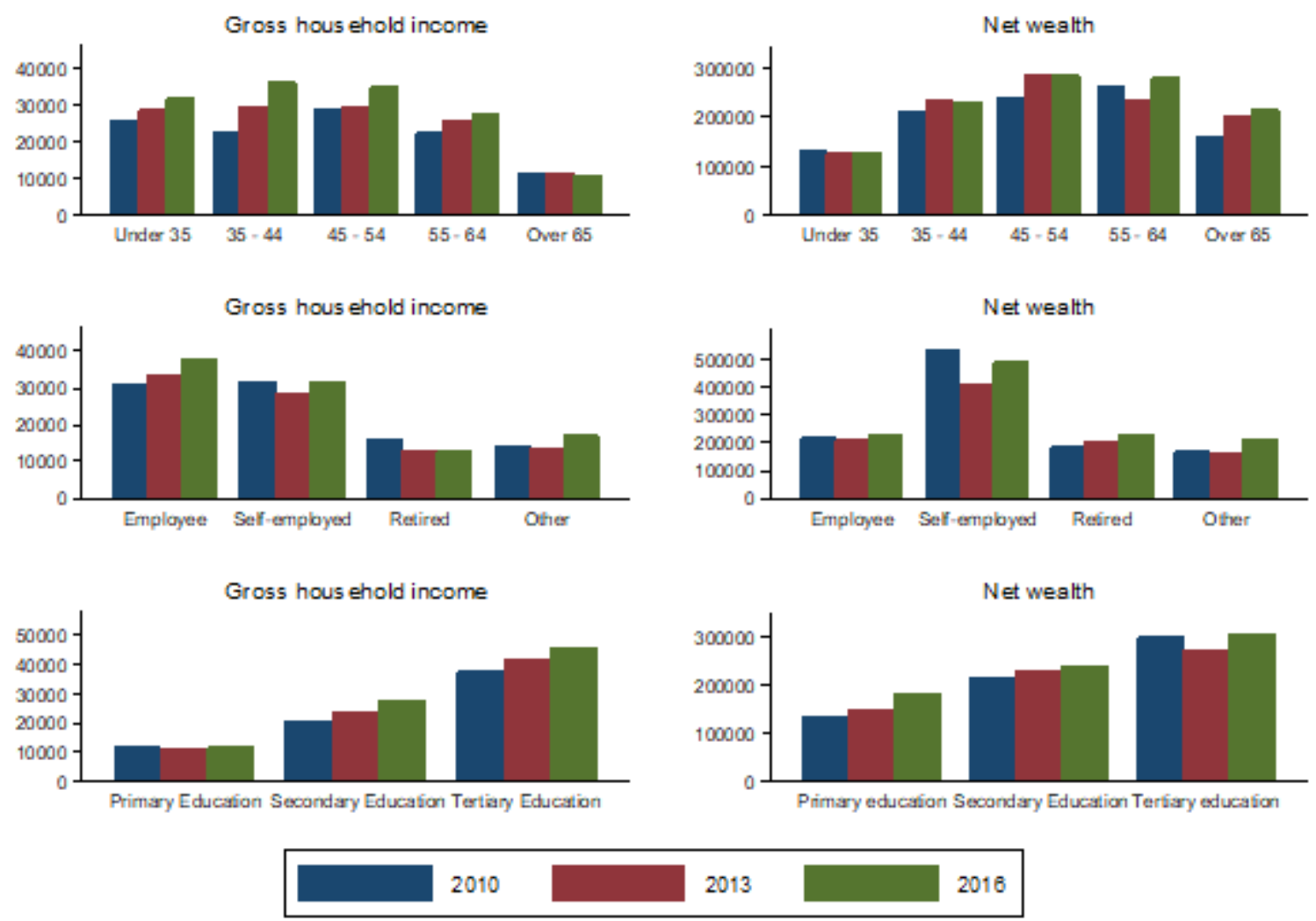

Source: MT-HFCS, Auth or's calculations

Figure 2. The distribution of median gross income and net wealth by age, employment status and education

\subsection{Inequality by Education Level}

The distribution of income and net wealth by education level is depicted in the bottom row of Figure 2. It is evident that there exists a close association between education and economic performance. For example, households with better-educated reference persons have higher incomes than their less-educated counterparts, and the respective absolute gap has widened across the three waves. However, in relative terms, those with tertiary education earned 1.7 times the income of those with secondary education in 2016, slightly lower than the 1.8 ratio recorded in 2010. For less-educated persons, the income gap between households with secondary and primary education increased considerably. The ratio stood at 2.4 in 2016, from 1.8 in 2010. A slightly different picture emerges with regards to net wealth. The gap between those with secondary education and primary education decreased since 2010, standing at 1.3 in 2016. In addition, in 2016, households with tertiary education held 1.3 times more net wealth, compared to households with as secondary education, down from 1.4 in 2010.

\section{Income and Net Wealth Inequality Decomposed by Component}

This section examines which components of net wealth and income are important in determining overall inequality. To this end, the decomposition technique developed by Lerman and Yitzhaki (1985) is applied. According to this method, the contribution of different income and net wealth components to overall inequality is quantified by taking into account the share of each individual source in the total distribution, its own Gini index and its correlation with the given total distribution. In particular:

$$
G=\sum_{i=1}^{I} S_{i} G_{i} R_{i}
$$

where: 
G - net wealth (income) Gini coefficient

$S_{i}$ - share of source in total net wealth (income)

$\mathrm{G}_{\mathrm{i}}$ - Gini index of source

$\mathrm{R}_{\mathrm{i}}$ - The relative Gini correlation between net wealth (income) source and the distribution of total net wealth (income). is a form of rank correlation coefficient, similar to Pearson's correlation coefficient and its values are within the range $[-1,1]$.

Following the literature, the main focus of the analysis is on the relative contribution $\left(S_{i} G_{i} R_{i} / G\right)$ and marginal contribution $\left(S_{i} G_{i} R_{i} / G-S_{i}\right)$ of source $i$ to the overall Gini coefficient. The former represents how much of the observed inequality in income or wealth is due to inequality in source i. The latter measures the first round effect of a percentage change of the overall Gini coefficient in response to a unit change in one of the components of net wealth (income).

\subsection{Decomposition of Gross Household Income}

As can be seen in Table 3, income from employment and pensions accounts for around four fifths of total household income, while other income sources contribute significantly less. As evidenced from the marginal contribution row, income from pensions and social transfers tend to decrease inequality, with an increasing equalising effect of transfers since 2010. This reveals the significant impact of government benefits in reducing gross household income inequality.

Employee income drives up overall income inequality having by far the highest marginal contribution. Its contribution was slightly lower in 2016 than in 2010 (see marginal contribution panel in Table 3). On average, a 1\% increase (ceteris paribus) in employee income edges up inequality by some $0.1 \%$. Interestingly, an increase in income from pensions tends to decrease income inequality by roughly $0.2 \%$.

Table 3. Gini decomposition of total gross household income by component

\begin{tabular}{|c|c|c|c|c|c|c|c|}
\hline & & $\begin{array}{l}\text { Employee } \\
\text { income }\end{array}$ & $\begin{array}{l}\text { Self- } \\
\text { employed } \\
\text { income }\end{array}$ & $\begin{array}{l}\text { Income from } \\
\text { pensions (including } \\
\text { widows and } \\
\text { disability) }\end{array}$ & $\begin{array}{l}\text { Regular social } \\
\text { transfers } \\
\text { (except } \\
\text { pensions) }\end{array}$ & $\begin{array}{l}\text { Income from } \\
\text { financial } \\
\text { investment }\end{array}$ & $\begin{array}{c}\text { Other } \\
\text { household } \\
\text { income }\end{array}$ \\
\hline Income & 2010 & 0.630 & 0.109 & 0.162 & 0.020 & 0.038 & 0.042 \\
\hline share & 2013 & 0.840 & 0.092 & 0.168 & 0.029 & 0.033 & 0.040 \\
\hline$S_{i}$ & 2016 & 0.674 & 0.088 & 0.136 & 0.029 & 0.021 & 0.053 \\
\hline $\begin{array}{c}\text { Gini } \\
\text { correlation }\end{array}$ & $\begin{array}{l}2010 \\
2013\end{array}$ & $\begin{array}{l}0.842 \\
0.872\end{array}$ & $\begin{array}{l}0.539 \\
0.497\end{array}$ & $\begin{array}{l}-0.172 \\
-0.109\end{array}$ & $\begin{array}{l}-0.127 \\
-0.107\end{array}$ & $\begin{array}{l}0.423 \\
0.448\end{array}$ & $\begin{array}{l}0.680 \\
0.768\end{array}$ \\
\hline$R_{i}$ & 2016 & 0.908 & 0.585 & -0.271 & -0.178 & 0.308 & 0.765 \\
\hline \multirow{2}{*}{$\begin{array}{l}\text { Gini index } \\
G_{i}\end{array}$} & $\begin{array}{l}2010 \\
2013\end{array}$ & $\begin{array}{l}0.579 \\
0.587\end{array}$ & $\begin{array}{l}0.894 \\
0.899\end{array}$ & $\begin{array}{l}0.678 \\
0.690\end{array}$ & $\begin{array}{l}0.864 \\
0.842\end{array}$ & $\begin{array}{l}0.752 \\
0.808\end{array}$ & $\begin{array}{l}0.959 \\
0.988\end{array}$ \\
\hline & 2016 & 0.568 & 0.913 & 0.674 & 0.791 & 0.885 & 0.988 \\
\hline \multirow{3}{*}{$\begin{array}{c}\text { Relative } \\
\text { contribution } \\
S_{i} G_{i} R_{i} / G\end{array}$} & 2010 & 0.812 & 0.139 & -0.050 & -0.006 & 0.032 & 0.072 \\
\hline & 2013 & 0.828 & 0.105 & -0.031 & -0.006 & 0.030 & 0.078 \\
\hline & 2016 & 0.851 & 0.111 & -0.081 & -0.010 & 0.014 & 0.095 \\
\hline Marginal & 2010 & 0.182 & 0.030 & -0.212 & -0.025 & -0.006 & 0.030 \\
\hline \multirow{2}{*}{$\begin{array}{l}\text { contribution } \\
S_{i} G_{i} R_{i} / G-S_{i}\end{array}$} & 2013 & 0.188 & 0.012 & -0.197 & -0.035 & -0.003 & 0.035 \\
\hline & 2016 & 0.177 & 0.023 & -0.197 & -0.039 & -0.007 & 0.043 \\
\hline
\end{tabular}

\subsection{Decompositon of Net Wealth}

This subsection presents the results of the decomposition of net wealth. Table 4 suggests that the most important equalising asset is household main residence, with a marginal contribution of around $0.2 \%$. This is not surprising not only because home-ownership in Malta is around $81 \%$ according to the HFCS, but also due to the higher values of HMR compared to other forms of assets. Moreover, houses are more often than not associated with mortgage debt, and it is found that housing loans (marginal contribution of around $0.12 \%$ ) and other forms of loans (marginal contribution of around $0.01 \%$ ) tend to increase net wealth inequality.

The most unequally distributed real asset is self-employment business. Its relative contribution to the net wealth 
inequality is high compared to the rest of the real assets, whereas its marginal contribution is positive and on the high side, indicating that self-employment business increases net wealth inequality.

In terms of marginal contribution, other real estate assets display a decreasing contribution, from around $0.12 \%$ in 2010 to around $0.07 \%$ in 2016 , while self-employment business is increasingly positively affecting inequality. The negative contribution of HMR to net wealth inequality is now stronger than that for 2010. This is due to changes in the composition of wealth components, and as can be seen in Table 4 other real estate and self-employment business are the main contributors to net wealth inequality in 2016.

With regards to financial assets, their contribution to net wealth is much lower compared to real assets. This is related to a rather low share of financial assets in total net wealth and a relatively even distribution of the most widely held financial asset, that is, deposits. The former statement suggests that the equalising effect of deposits has decreased over time.

Table 4. Gini decomposition of net wealth by component

\begin{tabular}{|c|c|c|c|c|c|c|c|c|c|c|c|c|c|}
\hline & & HMR & $\begin{array}{c}\text { Other real } \\
\text { estate }\end{array}$ & $\begin{array}{c}\text { Seif- } \\
\text { employment } \\
\text { bus iness }\end{array}$ & Ve hicies & Va uables & De poe its & Sec unitles & $\begin{array}{c}\text { Investment } \\
\text { funds and } \\
\text { Ilisted } \\
\text { shares } \\
\end{array}$ & $\begin{array}{c}\text { Voluntary } \\
\text { privet } \\
\text { pensilonswhols } \\
\text { Ilta ins ura nce }\end{array}$ & $\begin{array}{c}\text { Other } \\
\text { financlal } \\
\text { assets }\end{array}$ & $\begin{array}{l}\text { Housing } \\
\text { loa na }\end{array}$ & $\begin{array}{l}\text { Other } \\
\text { loans }\end{array}$ \\
\hline $\begin{array}{l}\text { Wesith } \\
\text { share }\end{array}$ & $\begin{array}{l}2010 \\
2013\end{array}$ & $\begin{array}{l}0.544 \\
0.588\end{array}$ & $\begin{array}{l}0.285 \\
0.219\end{array}$ & $\begin{array}{l}0.100 \\
0.182\end{array}$ & $\begin{array}{l}0.034 \\
0.039\end{array}$ & $\begin{array}{l}0.014 \\
0.007\end{array}$ & $\begin{array}{l}0.073 \\
0.055\end{array}$ & $\begin{array}{l}0.019 \\
0.013\end{array}$ & $\begin{array}{l}0.020 \\
0.019\end{array}$ & $\begin{array}{l}0.028 \\
0.021\end{array}$ & $\begin{array}{l}0.009 \\
0.007\end{array}$ & $\begin{array}{l}-0.105 \\
-0.127\end{array}$ & $\begin{array}{l}-0.022 \\
-0.023\end{array}$ \\
\hline$S_{i}$ & 2016 & 0.443 & 0.267 & 0.281 & 0.031 & 0.008 & 0.047 & 0.007 & 0.017 & 0.019 & 0.011 & -0.113 & -0.016 \\
\hline $\begin{array}{c}\text { Giri } \\
\text { cornelation }\end{array}$ & $\begin{array}{l}2010 \\
2013\end{array}$ & $\begin{array}{l}0.788 \\
0.743\end{array}$ & $\begin{array}{l}0.867 \\
0.830\end{array}$ & $\begin{array}{l}0.857 \\
0.825\end{array}$ & $\begin{array}{l}0.458 \\
0.417\end{array}$ & $\begin{array}{l}0.676 \\
0.727\end{array}$ & $\begin{array}{l}0.448 \\
0.512\end{array}$ & $\begin{array}{l}0.670 \\
0.715\end{array}$ & $\begin{array}{l}0.570 \\
0.654\end{array}$ & $\begin{array}{l}0.405 \\
0.225\end{array}$ & $\begin{array}{l}0.7 a 9 \\
0.774\end{array}$ & $\begin{array}{l}0.254 \\
0.065\end{array}$ & $\begin{array}{l}-0.174 \\
0.242\end{array}$ \\
\hline$R_{i}$ & 2016 & 0.710 & 0.894 & 0.957 & 0.481 & 0.524 & 0.600 & 0.472 & 0.729 & 0.432 & 0.851 & 0081 & -0.186 \\
\hline Giri index & $\begin{array}{l}2010 \\
2013\end{array}$ & $\begin{array}{l}0.378 \\
0.327\end{array}$ & $\begin{array}{l}0.826 \\
0.798\end{array}$ & $\begin{array}{l}0.941 \\
0.934\end{array}$ & $\begin{array}{l}0.527 \\
0.524\end{array}$ & $\begin{array}{l}0.936 \\
0.951\end{array}$ & $\begin{array}{l}0.603 \\
0.579\end{array}$ & $\begin{array}{l}0.829 \\
0.920\end{array}$ & $\begin{array}{l}0.905 \\
0.919\end{array}$ & $\begin{array}{l}0.813 \\
0.804\end{array}$ & $\begin{array}{l}0.978 \\
0.983\end{array}$ & $\begin{array}{l}-0.773 \\
-0.694\end{array}$ & $\begin{array}{l}-0.782 \\
-0.807\end{array}$ \\
\hline$G_{i}$ & 2016 & 0.364 & 0.902 & 0.943 & 0.523 & 0.882 & 0.637 & 0.941 & 0.957 & 0.874 & 0.983 & -0.628 & -0.821 \\
\hline \multirow{3}{*}{$\begin{array}{l}\text { Relative } \\
\text { contibufion } \\
S_{i} G_{i} R_{i} / G\end{array}$} & 2010 & 0.325 & 0.409 & 0.162 & 0.017 & 0.018 & 0.040 & 0.023 & 0.021 & 0.018 & 0.014 & -0.041 & -0.006 \\
\hline & 2013 & 0.288 & 0.292 & 0.281 & 0.017 & 0.010 & 0.033 & 0.017 & 0.023 & 0.008 & 0.010 & 0012 & 0.009 \\
\hline & 2016 & 0.177 & 0.333 & 0.393 & 0.012 & 0.004 & 0.028 & 0.005 & 0.019 & 0.011 & 0.015 & 0.009 & -0.004 \\
\hline \multirow{2}{*}{$\begin{array}{l}\text { Marginal } \\
\text { contibufion } \\
S_{i} G_{i} R_{i} / G-S_{i}\end{array}$} & $\begin{array}{l}2010 \\
2013\end{array}$ & $\begin{array}{l}-0.219 \\
-0.300\end{array}$ & $\begin{array}{l}0.124 \\
0.073\end{array}$ & $\begin{array}{l}0.082 \\
0.099\end{array}$ & $\begin{array}{l}-0.018 \\
-0.022\end{array}$ & $\begin{array}{l}0.004 \\
0.003\end{array}$ & $\begin{array}{l}-0.034 \\
-0.022\end{array}$ & $\begin{array}{l}0.004 \\
0.004\end{array}$ & $\begin{array}{l}0.001 \\
0.004\end{array}$ & $\begin{array}{l}-0.009 \\
-0.013\end{array}$ & $\begin{array}{l}0.005 \\
0.004\end{array}$ & $\begin{array}{l}0.064 \\
0.139\end{array}$ & $\begin{array}{l}0.016 \\
0.033\end{array}$ \\
\hline & 2016 & -0.266 & 0.066 & 0.111 & -0.019 & 0.002 & -0.019 & -0.002 & 0.001 & -0.008 & 0.003 & 0.122 & 0.012 \\
\hline
\end{tabular}

\section{The Joint Distribution of Income and Wealth}

This section investigates the joint distribution of income and wealth. In doing so, a transition matrix based on the quintile distributions of both variables is constructed. To assess how re-ranking among households has evolved between the three waves, results from 2010 and 2016 are presented, alongside the Shorrocks mobility index (see Azpitarte, 2010) (Note 5).

The high values of the Shorrocks index presented in Table 5 indicate a high re-ranking between the two distributions. Indeed, around $31 \%$ of households in the bottom income quintile were in the bottom net wealth quintile in 2016, compared to $37 \%$ in 2010. Similarly, in the top income quintile around $40 \%$ were in the top net wealth quintile in 2016 as opposed to $38 \%$ in 2010. From a different perspective, it implies a weak relationship between income and wealth, which is further supported by the low correlation coefficient between income and wealth (less than 0.45 in all waves) (Note 6).

In view of the above considerations, the position of a household in the income distribution is not a very good predictor of its position in the wealth distribution, except for households in the top income and net wealth quintile. This is mainly driven by pensioners who have low income levels due to low pensions, but are asset rich as a result of their large housing wealth. In fact, around $26 \%$ of households are in the bottom two income quintiles but in the highest net wealth quintile. To support this statement, Table 6 displays the joint distribution of income and net wealth across quintiles, excluding pensioners. It is now observed that around $28 \%$ of households are in the two bottom income quintiles, but in the highest wealth quintile in 2016. This percentage is close to the one found for the whole sample. Examining the percentage of households in the bottom two quintiles of income of the sample size as a whole and of the restricted sample, it is found that that $56 \%$ and $67 \%$ of households belong to the lower two income quintiles in 2016, respectively. Hence, it seems that the inclusion of pensioners only reduces the percentage of households in the lower quintiles of income, while the percentage of households in the bottom two income quintiles and in the highest net wealth quintile is very similar for both sample sizes. 
Table 5. Joint distribution of income and net wealth across quintiles

\begin{tabular}{|c|c|c|c|c|c|}
\hline 2010 & \multicolumn{5}{|c|}{ Net wealth quintile (Shorrocks index $=0.909$ ) } \\
\hline $\begin{array}{l}\text { Income } \\
\text { quintile }\end{array}$ & 1 & 2 & 3 & 4 & 5 \\
\hline 1 & 36.9 & 22.4 & 19.7 & 12.5 & 8.6 \\
\hline 2 & 23.8 & 22.9 & 20.2 & 18.2 & 14.9 \\
\hline 3 & 20.5 & 26.5 & 19.4 & 19.3 & 14.3 \\
\hline 4 & 13.8 & 20.5 & 22.4 & 19.3 & 24.0 \\
\hline 5 & 5.7 & 8.2 & 18.0 & 30.5 & 37.6 \\
\hline 2016 & \multicolumn{5}{|c|}{ Net wealth quintile (Shorrocks index $=0.918$ ) } \\
\hline $\begin{array}{l}\text { Income } \\
\text { quintile }\end{array}$ & 1 & 2 & 3 & 4 & 5 \\
\hline 1 & 30.5 & 26.7 & 17.8 & 16.5 & 8.5 \\
\hline 2 & 25.7 & 18.4 & 21.4 & 16.9 & 17.7 \\
\hline 3 & 21.8 & 23.8 & 21.4 & 22.4 & 10.6 \\
\hline 4 & 16.0 & 16.8 & 22.7 & 22.3 & 22.1 \\
\hline 5 & 6.2 & 14.9 & 16.2 & 22.8 & 39.9 \\
\hline
\end{tabular}

Hence, retired households tend to push up net wealth, but put downward pressure on income levels. These opposite effects tend to weaken the correlation between income and wealth, amongst other things.

Table 6. Joint distribution of income and net wealth across quintiles for working-age households

\begin{tabular}{|c|c|c|c|c|c|}
\hline 2010 & \multicolumn{5}{|c|}{ Net wealth quintile (Shorrocks index $=0.905$ ) } \\
\hline \multicolumn{6}{|l|}{ Income } \\
\hline quintile & 1 & 2 & 3 & 4 & 5 \\
\hline 1 & 38.9 & 20.0 & 21.4 & 11.6 & 8.1 \\
\hline 2 & 26.7 & 26.2 & 22.6 & 13.0 & 11.5 \\
\hline 3 & 17.0 & 28.7 & 21.5 & 19.7 & 13.1 \\
\hline 4 & 14.2 & 20.0 & 25.4 & 18.5 & 22.0 \\
\hline 5 & 5.8 & 6.7 & 20.9 & 33.6 & 33.1 \\
\hline 2016 & \multicolumn{5}{|c|}{ Net wealth quintile (Shorrocks index $=0.893$ ) } \\
\hline $\begin{array}{l}\text { Income } \\
\text { quintile }\end{array}$ & 1 & 2 & 3 & 4 & 5 \\
\hline 1 & 36.1 & 37.8 & 7.7 & 5.9 & 12.4 \\
\hline 2 & 31.3 & 21.9 & 18.0 & 13.2 & 15.5 \\
\hline 3 & 14.9 & 30.2 & 27.1 & 20.9 & 6.9 \\
\hline 4 & 17.0 & 18.9 & 26.0 & 20.1 & 18.0 \\
\hline 5 & 5.7 & 16.6 & 16.6 & 23.7 & 37.4 \\
\hline
\end{tabular}

Motivated by the findings described above, the focus of the analysis is now shifted to examine factors that influence the position of a household in the net wealth distribution. For this purpose, a generalised ordered logit model for the probability of a household to be in a net wealth quintile given its position in the income distribution after also controlling for socioeconomic and demographic features is estimated: 


$$
\operatorname{Pr}\left(y_{i}>j\right)=F\left(a_{j}+\beta^{\prime} x_{i}\right), \quad j=0,1, \ldots, J-1
$$

where, $y_{i}$ is an ordered categorical variable, $J$ is the number of categories of $y_{i}, J-1$ is the number of thresholds required to divide the range of $y$ into $J$ categories, $x_{i}$ is a vector that contains control variables other than the constant term and $\mathrm{F}$ is the standard cumulative distribution function. The model estimates $\mathrm{J}-1$ binary regressions, that is, for values $j=1, \ldots J-1$, equation $J-1$ compares the choice between categories $1, \ldots . J-1$ versus category $\mathrm{J}$, while the higher the $\beta_{\mathrm{j}}\left(\beta_{\mathrm{j}}>0\right)$ is the higher the probability of moving from one category to another $j$. The generalised ordered model, as opposed to a standard ordered model, allows for greater flexibility in linking wealth and income, but, more importantly, for heterogeneous effects of the explanatory variables across the categories of the dependent variable (Williams, 2006; Greene \& Hensher, 2010). This model estimates the odds of being beyond a certain category relative to being at or below that category. More specifically, the model estimates a separate vector of coefficients $\beta_{j}^{\prime}$ for each of the $J-1$ categories of the response variable.

The dependent variable of the model is net wealth quintiles. Control variables include income quintiles, the number of household members, gender, age, education level and labour status of the reference person, a dummy which is one if a household has received inheritance or gifts, and two dummies related to the financing structure of the HMR, namely owner-outright and owner with mortgage (as distinct from renters). The former indicates whether a household financed part or all of its HMR with its own resources, namely savings used for down payment or for the total purchase. The latter shows if a household financed its HMR with mortgage either completely or partially. These dummy variables are considered as proxies in order to capture the economic condition of a household in the past, which is also an indication of the wealth accumulation process of each household over time. In this framework, the reference groups are households in the first income quintile, whose reference person is an employee, has a primary level of education and belongs to other/renter category. Overall, similar frameworks can be found in Arrondel et al. (2014) and Martinez and Uribe (2018).

Table 7. Generalised ordered logit regression results

\begin{tabular}{|c|c|c|c|c|}
\hline & $\begin{array}{l}\text { 1st } \\
\text { Wealth } \\
\text { threshold }\end{array}$ & $\begin{array}{l}\text { 2nd } \\
\text { Wealth } \\
\text { threshold }\end{array}$ & $\begin{array}{l}\text { 3rd } \\
\text { Wealth } \\
\text { threshold }\end{array}$ & $\begin{array}{l}\text { 4th } \\
\text { Wealth } \\
\text { threshold }\end{array}$ \\
\hline 2nd Income quintile & 0.115 & $0.591^{\star \star \star}$ & $0.434^{*}$ & $0.825^{\star \star}$ \\
\hline 3rd Income quintile & $1.038^{* *}$ & $1.281^{* * *}$ & $1.122^{* * *}$ & $1.279^{\star \star \star *}$ \\
\hline 4th Income quintile & $0.928^{*}$ & $1.642^{* * *}$ & $1.340^{* \star *}$ & $1.758^{\star \star \star *}$ \\
\hline 5th Income quintile & $1.662^{\star \star \star}$ & $2.117^{\star \star \star \star}$ & $2.252^{\star \star \star}$ & $2.879^{\star \star \star *}$ \\
\hline Gender & -0.282 & -0.104 & 0.185 & 0.041 \\
\hline Age of reference person & $0.429^{\star \star \star *}$ & $0.456^{\star \star \star *}$ & $0.375^{\star \star \star}$ & $0.418^{\star \star *}$ \\
\hline Household size & -0.049 & 0.141 & 0.055 & -0.146 \\
\hline Secondary education & $0.926^{\star \star \star *}$ & 0.349 & $0.354^{\star}$ & 0.397 \\
\hline Tertiary education & $1.425^{\star \star \star}$ & $1.111^{* \star *}$ & $1.103^{\star \star \star *}$ & $1.155^{\star \star \star \star}$ \\
\hline Self-employed & 0.757 & $1.223^{* * *}$ & $1.844^{* \star *}$ & $2.426^{* * *}$ \\
\hline Retired & -0.329 & 0.135 & 0.173 & 0.508 \\
\hline Other & $-1.156^{\star *}$ & 0.001 & 0.116 & 0.388 \\
\hline Owner outright & $5.251^{\star \star \star \star}$ & $3.484^{\star \star \star *}$ & $4.622^{\star \star *}$ & 17.273 \\
\hline Owner with mortgage & $3.961^{* * *}$ & $2.406^{\star \star \star \star}$ & $3.527^{\star \star \star \star}$ & 16.704 \\
\hline Credit-constrained households & $-1.707^{\star \star \star *}$ & -0.451 & 0.338 & 0.763 \\
\hline Inheritance/gifts & $0.953^{* * *}$ & $1.149^{* \star \star}$ & $0.877^{\star * *}$ & $0.491^{\text {** }}$ \\
\hline Pseudo R2 & 0.28 & & & \\
\hline N.Obs & 996 & & & \\
\hline \multicolumn{5}{|c|}{$\begin{array}{l}\text { Source: MT - HFCS, Author's calculations } \\
\text { **** denotes significant at 1-percent level; }{ }^{* *} \text { denotes significant at 5-percent level; " denotes } \\
\text { significant at } 10 \text {-percent level }\end{array}$} \\
\hline \multicolumn{5}{|c|}{$\begin{array}{l}\text { All estimates are weighted using household weights and take the multiple imputation structure } \\
\text { into account }\end{array}$} \\
\hline
\end{tabular}

Table 7 presents the regression results of the generalised ordered logit model. The estimated coefficients of the income quintiles are positive and in most cases, significant. In other words, a rise in income increases the probability of being in a higher net wealth quintile with the exception of the fourth income quintile in the first net wealth threshold. Furthermore, within a given net wealth threshold, the estimated coefficients increase with income, suggesting that the probability of belonging to a given net wealth quintile increases along the income distribution, except for the first wealth threshold and fourth income quintile. The significance of income in the stock of household wealth and 
distribution is very common in the literature (see e.g. Fessler \& Schürz, 2015).

With reference to housing status, there exists a positive and significant impact on the probability of a household to be in a higher quintile in the wealth distribution for households who own their homes with no outstanding mortgages, except for the highest net wealth quintile. Hence, households that can save up enough money to partly or fully finance the purchase of a house have a high probability of being in the wealthiest quintiles in the future. With regards to households with a mortgage, this variable explains the position of households in the wealth distribution in a positive and significant way. This is related to the fact that households with mortgage are those with higher expected incomes and therefore, represent a lower risk to financial institutions. Overall, one could argue that the financing structure of the household home is an indicator of the household wealth position today.

Moving on to the effects of the other control variables, the age of the reference person is found to have a positive impact on the positon in the distribution of wealth. Gender seems to have mixed effects on the position of a household in the wealth distribution, but this dummy variable is not statistically significant. Households with a self-employed reference person are more likely to be in a higher wealth quintile, mainly due to the high value asset holdings. Household size is ambiguous and statistically insignificant. This could be attributed to the similar household structure across wealth quintiles (see Mathä et al., 2014). Credit-constrained households in the first wealth quintile are negatively affected by the lack of credit, but there is no statistically significant effect in the rest of the wealth distribution. In addition, the inheritance dummy is significant and positive, indicating that having received gifts or inheritance has a positive impact on the position in the wealth distribution. Finally, education has a positive impact on the position in the net wealth distribution.

\section{Conclusion}

The aim of this paper is to study income and wealth inequality in Malta in the period 2010/16, during which the Maltese economy experienced strong macroeconomic growth. Based on micro-level data from the Household Finance and Consumption Survey, various socioeconomic aspects of the distribution of income and wealth are examined. Moreover, factors that drive a household's position in the income and wealth distribution, mobility across the distributions are explored.

Similar to findings for other countries, wealth inequality in Malta is more pronounced than income inequality. However, wealth inequality increased moderately between 2010 and 2016, mainly driven by self-employment business, followed by other real estate properties and widened at a quicker pace than income inequality. In relative terms, wealth and income distribution changed somewhat in favour of households in the upper parts of the distributions.

The decomposition analysis suggests that inequality in labour income lead to greater overall income inequality, while income from pensions has the opposite effect. Furthermore, household main residence is the most equalising factor of wealth inequality, while self-employment wealth is the most disequalising factor. The role of the financial assets and indebtedness is rather limited.

As regards the factors that influence the position of a household in the wealth distribution, results indicate that higher household income levels tends to increase the probability of being in a higher net wealth quintile. More importantly, the financing structure of a household's main residence is crucial to explain its position in the wealth distribution, as is the incidence of having received inheritance or gifts.

\section{Acknowledgements}

The author likes to thank Mr Alexander Demarco, Dr Aaron Grech, Ms Rita Schembri, Mr Brian Micallef, Mr Silvio Attard, one external reviewer and attendants of two internal seminars of the Economics Division at the Central Bank of Malta for helpful comments and suggestions.

\section{Disclaimer}

The views expressed in this paper are those of the author and do not necessarily reflect those of the Central Bank of Malta. Any errors are the author's own.

\section{References}

Arrondel, L., Roger, M., \& Savignac, F. (2014). Wealth and income in the Euro Area: Heterogeneity in households hehaviours, Working Papers Series No. 1709, European Central Bank. https://doi.org/10.2139/ssrn.2469142

Azpitarte, F. (2010). The household wealth distribution in Spain: The role of housing and financial wealth, Hacienda Publica Española/Revista de Economia Publica, 194(3), 65-90.

Betti, G., Caruana, E., Gusman, S., \& Neri, L. (2015). Economic poverty and inequality at regional level in Malta: Focus on the situation of children, Economic Region, 2, 114-122. https://doi.org/10.17059/2015-3-10 
Bezrukovs, D. (2013). The role of housing in wealth inequality in Eurozone countries, Master's thesis, Goethe Universitat.

Bilias, Y., Georgarakos, D., \& Haliassos, M. (2005). Equity culture and the distribution of wealth. Working Paper Series No. 2005/20, Centre for Financial Studies.

Bourguignon, F., Ferreira, F. \& Leite, P. (2008). Beyond Oaxaca-Blinder: Accounting for differences in household income distributions. The Journal of Economic Inequality, 6(2), 117-148. https://doi.org/10.1007/s10888-007-9063-y

Brandolini, A., Cannari, L., D’Alessio, G., \& Faiella, I. (2004). Household wealth distribution in Italy in the 1990s, Working Paper No. 414, Bank of Italy.

Bricker, J., Krimmel, J., Henriques, A., \& Sabelhaus, J. (2016). Measuring income and wealth at the top using administrative and survey data, Brookings Papers on Economic Activity. https://doi.org/10.2139/ssrn.2670956

Chernozhukov, V., Fernandez-Val, I., \& Melly B. (2009). Inference on counterfactual distributions, Working Papers CWP09/09, Centre for Microdata Methods and Practice, Institute for Fiscal Studies. https://doi.org/10.2139/ssrn.1235529

Cowell, F., Nolan, B., Olivera, J., \& Van Kerm, P. (2016). Wealth, top incomes and inequality, Working Papers 24, LIS Cross-National Data Centre in Luxembourg. https://doi.org/10.1093/oso/9780198803720.003.0008

Darmanin, J., Georgakopoulos, I., \& Knoppe, C. (2018). Income distribution, inequality and mobility in Malta, Research Bulletin, Central Bank of Malta.

Davies, J., \& Shorrocks, A. (2000). The distribution of wealth, Handbook of Income Distribution, 1, 605-675, Amsterdam: North-Holland. https://doi.org/10.1016/S1574-0056(00)80014-7

Fessler, P., \& Schürz, M. (2015). Private wealth across European countries: The role of income, inheritance and the welfare state, Working Papers Series No. 1847, European Central Bank.

Fortin, N., M., Lemieux, T., \& Firpo, S. (2011). Decomposition methods in economics. Handbook of Labour Economics, 4A, 1-102. https://doi.org/10.1016/S0169-7218(11)00407-2

Greene, W., \& Hensher, D. (2010). Modelling ordered choices. Cambridge Books: Cambridge University Press. https://doi.org/10.1017/CBO9780511845062

Grejcz, K., \& Żółkiewski, Z. (2017). Household wealth in Poland: The results of a new survey of household finance, Bank i Kredyt, 48(3), 295-326.

Jäntti, M., Sierminska, E., \& Smeeding, T. (2008). The joint distribution of household income and wealth: Evidence from the Luxembourg Wealth Study, Social, Employment and Migration Working Paper No. 65, Organisation for Economic Co-operation and Development.

Jäntti, M., Sierminska, E., \& Van Kerm, P. (2013). The joint distribution of income and wealth. On J. C. Gornick, \& M. Jäntti (Eds), Income inequality. Economic Disparities and the Middle Class in Affluent Countries (pp. 312-330). Stanford University Press. https://doi.org/10.11126/stanford/9780804778244.003.0012

Knoppe, C. (2018). Wage income distribution and mobility in Malta, Working Paper No. 6, Central Bank of Malta.

Kontbay-Busun, A., \& Peichl, A. (2015). Multidimensional affluence in income and wealth in the Eurozone: A cross-country comparison using HFCS, Discussion Paper No. 9139, Institute of Labour Economics. https://doi.org/10.2139/ssrn.2562315

Leitner, S. (2016). Drivers of wealth inequality in Euro Area countries, Working Paper No. 122, The Vienna Institute for International Economic Studies.

Lerman, R. I., \& Yitzhaki, S. (1985). Income inequality effects by income source: A new approach and applications to the United States, The Review of Economics and Statistics, 67(1), 151-156. https://doi.org/ 10.2307/1928447

Lindner, P., (2015). Factor decomposition of the wealth distribution in the Euro Area, Empirica, 42(2), 291-322. https://doi.org/10.1007/s10663-015-9290-6

Machado, J., A., F., \& Mata, J. (2005). Counterfactual decomposition of changes in wage distributions using quantile regression. Journal of Applied Economics, 20(4), 445-465. https://doi.org/10.1002/jae.788

Martinez, F., \& Uribe, F. (2018). Determinants of household position in the wealth distribution in Chilean households, Working Paper No. 827, Central Bank of Chile.

Mathä, T., Porpiglia, A., \& Ziegelmeyer, M. (2014). Household wealth in the Euro Area: The importance of 
intergenerational transfers, homeownership and house price dynamics, Working Paper Series No. 1690, European Central Bank. https://doi.org/10.2139/ssrn.2487119

Piketty, T. (2014). Capital in the 21st century. Cambridge: Harvard University Press. https://doi.org/10.4159/9780674369542

Rani, U., \& Furrer, M. (2016). Decomposing income inequality into factor income components: Evidence from selected G20 countries, Research Paper No. 15, International Labour Organisation.

Rubin, D. B. (1987). Multiple imputation for nonresponse in survey. New York: John Wiley \& Sons. https://doi.org/10.1002/9780470316696

Shorrocks, A. F. (1982). Inequality decomposition by factor components, Econometrica, 50(1), 193-211. https://doi.org/0.2307/1912537

Shorrocks, A. F. (1983). The impact of income components on the distribution of family incomes, The Quarterly Journal of Economics, 98(2), 311-326. https://doi.org/10.2307/1885627

Sierminska, E., \& Smeeding, T. (2005). Measurement issues: equivalence scales, accounting framework and reference unit, paper prepared for LWS Workshop: Construction and Usage of Comparable Microdata on Wealth: the LWS, Perugia, Italy, 27-29 January 2005.

Stiglitz, J. E., Sen, A., \& Fitoussi, J., P. (2009). Report by the Commission on the Measurement of Economic Performance and Social Progress.

Williams, R. (2006). Generalized ordered logit/partial proportional odds models for ordinal dependent variables, The Stata Journal, 6, 58-82. https://doi.org/10.1177/1536867X0600600104

Wolff, N. E. (1994). Trends in the household wealth in the United States, 1962-63 and 1983-89, Review of Income and Wealth, 40(2). https://doi.org/10.1111/j.1475-4991.1994.tb00056.x

Wolff, N. E. (2004). Changes in household wealth in the 1980s and 1990s in the U.S, Economics Working Paper No. 407, Levy Economics Institute.

\section{Notes}

Note 1. The Household Finance and Consumption Survey also suggests a high home-ownership rate.

Note 2. Fieldwork was conducted in those years but data refer to preceding year. Only exception is 2010 as data are for 2010.

Note 3. For a debate see Davies and Shorrocks (2000), Sierminska and Smeeding (2005) and Jäntti et al. (2013).

Note 4. The 'Other' category includes those classified as unemployed, student/pupil/unpaid intern, permanently disabled, those in compulsory military service or equivalent social service, those fulfilling domestic task and those classed as other not working for pay.

Note 5. The Shorrocks index is based on the information on the diagonal of the transition matrix $M=[n-\operatorname{trace}(\mathrm{P})] /(\mathrm{n}-$ 1). A Shorrocks index of 1 means that there is complete mobility, while when there is no mobility the index is equal to zero. It is important to keep in mind that mobility in this analysis does not measure the joint evolution over time of the same individuals in the wealth and income distributions. It rather measures mobility within the joint distribution at two separate times. However, we note that when we repeat the analysis for the panel component of survey to trace rank mobility of households over time, the qualitatively results do not differ significantly compared to those in Table 5 .

Note 6. The weak correlation between income and wealth is often found in the literature (see e.g. Kontbay-Busun \& Peichl, 2015). Self-employment and housing (or home equity) are wealth components that provide highly idiosyncratic returns. Owner-occupied houses provide a financial return but they also provide nonpecuniary returns. Given their importance in the Maltese household portfolio, the weak correlation of income and wealth is possibly due to the components of wealth.

\section{Copyrights}

Copyright for this article is retained by the author(s), with first publication rights granted to the journal.

This is an open-access article distributed under the terms and conditions of the Creative Commons Attribution license which permits unrestricted use, distribution, and reproduction in any medium, provided the original work is properly cited. 